Рибидайло А. А., к.т.н., с.н.с.;

Турейчук А. М., к.т.н.;

Прокопенко О. С.;

Дергильова О. В., к.т.н., с.н.с.

Центр воєнно-стратегічних досліджень Національного університету оборони України імені Івана Черняховського, Київ

\title{
Формування дісвого резерву кандидатів для просування по службі та його використання під час підготовки і прийняття кадрових рішень
}

Резюме. Проведено аналіз процесу управління особовим складом щодо формування і використання Резерву кандидатів для просування по службі та управління кар'єрою військовослужбовців. Обгрунтовані пропозиції щодо удосконалення процесу формування Резерву за рейтинговим принципом шляхів застосування IT-технологій.

Ключові слова: кадровий резерв, комплектування збройних сил, автоматизовані системи управління персоналом.

Постановка проблеми. Політичне протистояння на Сході України, що виникло навесні 2014 року, переросло в затяжний збройний конфлікт. Прагнення розв'язати конфлікт силовим шляхом обернулися численними людськими жертвами 3 обох сторін. 3 метою припинення подальшого кровопролиття і встановлення миру в регіоні, сторони конфлікту за участю міжнародних посередників пішли на укладення Мінських угод.

Мінські угоди - загальна назва документів, які передбачають припинення вогню на території Донецької та Луганської областей, а також послідовний комплекс заходів військового, політичного, економічного та гуманітарного характеру, спрямований на мирне врегулювання збройного конфлікту на території областей.

Мінські домовленості не $є$ ідеальним i прийнятним для всіх залучених сторін документом. Це був компроміс між бажаним i реальним. На думку міжнародних експертів конфлікт на Донбасі перейшов у затяжну фазу.

Близькі до Кремля експерти вважають найбільш імовірним сценарій заморожування конфлікту на Сході України на довгі роки, або назавжди. Про це йдеться в доповіді Центру політичної кон'юнктури. Імовірність реалізації "песимістичного сценарію" заморозки конфлікту на довгі роки експерти центру оцінили у $50 \%$ [1].

Конфлікт на Сході України буде якийсь час ще тривати. Таку думку висловлюють політичні експерти на аналітичному порталі “Слово і Діло”. Вони зазначають, що війна закінчується, коли одна зі сторін втрачає ресурс на війну i, як наслідок, приймає умови іншої. Поки ресурс $є$ у обох сторін, війну зупинити неможливо. На сьогодні Україна має ресурс, адже триває підтримка Заходу. Ресурс є і у Росії, яка адаптувалася під нові реалії i знаходить можливості в комунікації з країнами поза Заходу. Україна хоче суверенного шляху до Заходу, а Росія контролю над Україною. Це несумісні речі, тому війна триватиме [2].

В Україні в умовах особливого періоду вже проведено иicmb черг часткової мобілізації, в результаті яких відбулось масове надходження людських ресурсів до ЗС України.

Таким чином, нагальним постає питання формування військового резерву, тобто певного складу громадян, що пройшли підготовчий відбір (оцінювання) i мають необхідний потенціал для виконання прямих обов'язків на необхідній посаді у встановлені терміни.

Для підвищення прозорості та оперативності у прийнятті кадрових рішень щодо призначення військовослужбовців на посади доцільно використовувати рейтинговий принцип.

Аналіз останніх досліджень i публікацій. Формування дієвого Резерву кандидатів для просування по службі та забезпечення його ефективного використання кадровими органами Збройних Сил України вимагає проведення певних досліджень, які можна подати у вигляді структурно-логічної схеми, наведеної на рис. 1:

У джерелах [3-5] висвітлені особливості формування військового Резерву у провідних країнах світу. У роботі [6] проведено 
узагальнення досвіду армій провідних країн світу щодо створення кадрового резерву та аналіз світових тенденцій щодо автоматизації процесів кадрового менеджменту.

\begin{tabular}{|c|c|c|}
\hline \multicolumn{3}{|c|}{ НАПРЯМИ ДОСЛІДЖЕНЬ } \\
\hline $\begin{array}{l}\text { Аналіз передового досвіду щодо } \\
\text { формування та використання } \\
\text { кадрового резерву збройних сил }\end{array}$ & \begin{tabular}{|l} 
Аналіз існуючого порядку \\
формування Резерву кандидатів \\
для просування по службі у \\
Збройних Силах України
\end{tabular} & \begin{tabular}{|l} 
Аналіз \\
бази щодо пормативно-правової \\
використання Резерву кандидатів у \\
Збройних Силах України
\end{tabular} \\
\hline
\end{tabular}

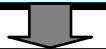

\section{Потреби органів кадрового менеджменту ЗС України}

\section{ШЛЯХИ УДОСКОНАЛЕННЯ (РОЗРОБЛЕННЯ ПРОПОЗИЦИЙ)}

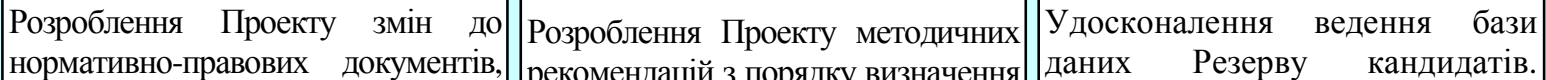
нормативно-правових документів, які регламентують порядок формування та використання Резерву кандидатів у ЗС України

рекомендацій з порядку визначення
рейтингу в військовослужбовців
Збройних Сил України
Розроблення експериментального макету АРМ та методики його використання

\section{Стратегія впровадження результатів}

Рис. 1. Структурно-логічна схема досліджень

Формування Резерву кандидатів для просування по службі кадровими органами Збройних Сил України регламентується відповідними нормативно-правовими актами (понад 20 документів), основні з яких наведено у табл. 1.

Таблиця 1.

\begin{tabular}{|c|l|}
\hline № & \multicolumn{1}{|c|}{ Назва документа } \\
\hline 1 & Конституція України \\
\hline 2 & Закон України “Про Збройні Сили України” від 06.12.1991 № 1934-ХІІ \\
\hline 3 & Закон України “Про військовий обов’язок і військову службу” від 04.04.2006 № 3597-IV \\
\hline 4 & Закон України від 21.10.1993 “Про мобілізаційну підготовку та мобілізацію” \\
\hline 5 & $\begin{array}{l}\text { Закон України від 25.03.1992 року № 2233 (зі змінами) “Про військовий обов’язок і військову } \\
\text { службу” }\end{array}$ \\
\hline 6 & $\begin{array}{l}\text { Наказ Міністра оборони України від 31.03.2008 № 129 “Про затвердження програми реалізації } \\
\text { концепції кадрової політики в 3бройних Силах України” (зі змінами) }\end{array}$ \\
\hline 7 & $\begin{array}{l}\text { Наказ Міністра оборони України від 20.05.2009 № 233 “Про затвердження положення про типовий } \\
\text { алгоритм управління кар'єрою військовослужбовця та порядок його застосування” }\end{array}$ \\
\hline 8 & $\begin{array}{l}\text { Наказ Міністра оборони України від 15.10.2009 № 520 “Про затвердження положення про комісії } \\
\text { Збройних Сил України з відбору кандидатів до призначень на посади” }\end{array}$ \\
\hline 9 & $\begin{array}{l}\text { Наказ Міністра оборони України від 30.06.1993 № 140 “Про введення в дію порадника по роботі } \\
\text { кадрових органів Збройних Сил України” }\end{array}$ \\
\hline
\end{tabular}

Рейтинговий принцฺип при прийнятті кадрових рішень означає, що кожному кандидату на відповідну посаду надається кількісно-якісний рейтинг, на підставі якого приймаються рішення.

У роботі [7] запропоновано регламент по підбору персоналу, який включає такі заходи: визначення потреби у вакансії; ініціація процесу пошуку i підбору, визначення основних вимог до кандидата; вибір методів пошуку (внутрішній i/або зовнішній); формування бази резюме/анкет; первинний відбір по резюме/анкеті; проведення інтерв'ю; оцінювання кандидата; прийняття рішення; пропозиція про вихід на роботу.
Для реалізації процедури визначення рейтингу у прочесі підбору $i$ розстановки кадрів та під час розгляду кандидатів на навчання розроблено Методичні рекомендації 3 порядку визначення рейтингу військовослужбовців Збройних Сил України, затверджені директором Департаменту кадрової політики Міністерства оборони України від 29.12.2009 № 226/1/4545.

Метою статті $\epsilon$ висвітлення результатів аналізу існуючого порядку формування Резерву кандидатів для просування по службі у Збройних Силах України та формування пропозицій щодо удосконалення процесу формування Резерву за рейтинговим принципом шляхів застосування IT-технологій. 
Виклад основного матеріалу. Кадрові резерви - це громадяни держави, що плануються для призначення на необхідні посади. Такий запас кандидатур має умовну структуру. Кадровий резерв (професійний запас) може бути як внутрішнім, так i зовнішнім. Що стосується внутрішнього резерву, то він складається 3 діючих військовослужбовців і розділяється на оперативний і перспективний.

Формування зовнішнього резерву здійснюється зі складу військовозобов' язаних громадян держави. Щодо військового обов'язку, то в Україні громадяни підрозділяються на такі категорії:

- допризовники - особи, що підлягають приписці до призовних ділянок;

- призовники - особи, що приписані до призовних ділянок;
- військовослужбовці - особи, що проходять військову службу;

- військовозобов'язані - особи, що знаходяться в запасі для комплектування Збройних Сил України й інших військових формувань на особливий період, а також для виконання робіт по забезпеченню оборони держави;

- резервісти - особи, які проходять службу у військовому резерві Збройних Сил України, інших військових формуваннях і призначені для ïx комплектування в мирний час i особливий період.

Процес управління особовим складом щодо формування i використання Резерву кандидатів для просування по службі та управління кар'єрою військовослужбовців містить такі процеси (див. табл. 2).

\begin{tabular}{|c|l|}
\hline \multicolumn{1}{|c|}{ Ноазва підпроцесу } \\
\hline $\mathbf{1}$ & Облік всіх категорій населення України щодо військового обов’язку \\
\hline $\mathbf{2}$ & Розрахунок потреб Збройних Сил України на визначені терміни \\
\hline $\mathbf{3}$ & Відбір кандидатів для навчання до ВНЗ із призовників \\
\hline $\mathbf{4}$ & Відбір кандидатів для навчання до ВНЗ із військовослужбовців \\
\hline $\mathbf{5}$ & $\begin{array}{l}\text { Планування комплектування слухачами та розподіл випускників вищих військових навчальних } \\
\text { закладів Збройних Сил України }\end{array}$ \\
\hline $\mathbf{6}$ & $\begin{array}{l}\text { Формування схеми (шаблону) кар'єри, планування та супроводження кар'єри особового складу з } \\
\text { використанням визначеного алгоритму управління кар'єрою офіцерського, сержантського, } \\
\text { старшинського та рядового складу }\end{array}$ \\
\hline $\mathbf{7}$ & \begin{tabular}{l} 
Підтримка процесів підготовки і навчання особового складу \\
\hline $\mathbf{8}$
\end{tabular} $\begin{array}{l}\text { Кадровий маркетинг щодо підбору та розстановки кадрів на основі багатокритеріального пошуку } \\
\text { кандидатів і вакансій }\end{array}$ \\
\hline $\mathbf{9}$ & \begin{tabular}{l} 
Реалізація рейтингового відбору у процесі підбору і розстановки кадрів \\
\hline $\mathbf{1 0}$
\end{tabular} $\begin{array}{l}\text { Підготовка інформаційно-аналітичної звітності за всіма показниками персонального та штатно- } \\
\text { посадового обліку, формування статистичних звітів за формами, встановленими керівними } \\
\text { документами }\end{array}$ \\
\hline
\end{tabular}

Нині облік особового складу за встановленими формами здійснюється згідно 3 керівними документами в установах, які беруть участь у процесах кадрового менеджменту:

- Міністерство оборони та ГШ Збройних Сил України (І рівень);

- види Збройних Сил та оперативні командування (II рівень);

- об'єднання (III рівень);

- військові частини, військові комісаріати, органи місцевого самоврядування, підприємства, установи, навчальні заклади (IV рівень).

Розрахунок потреб Збройних Сил України на визначені терміни здійснюється на основі потоку термінових донесень, який регламентовано Директивою начальника Генерального штабу-Головнокомандувача 3С України № ДГШ-12 від 30 грудня 2005 року. Цей інформаційний потік класифіковано по розділах і він охоплюе практично всі структурні підрозділи системи кадрового менеджменту 3С України:

- 3 питань мобілізаційно-кадрової роботи (розділ I); II);

- $з$ організаційно-планових питань (розділ

- 3 питань аналізу, прогнозу та реалізації кадрової політики ЗС України (розділ III);

- 3 питань призову та комплектувань особовим складом (розділ IV);

- 3 питань присвоєння військових звань, нагород і відзнак МО України (розділ V);

- 3 питань реалізації міжнародних програм (розділ VI);

- 3 питань інформації, обліку та статистики (розділ VII).

Алгоритм відбору кандидатів із призовників для навчання у ВНЗ наведено на рис. 2. 


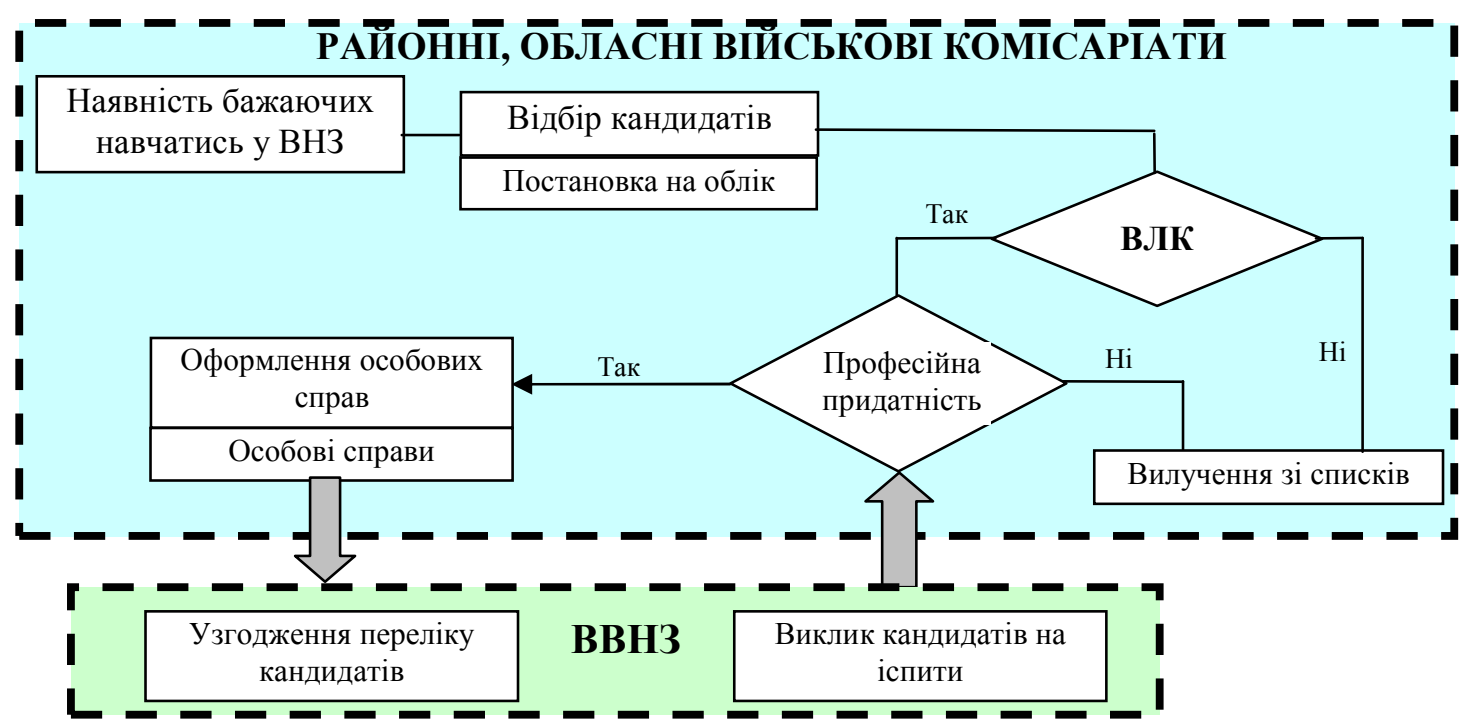

Рис. 2

Аналогічно цьому алгоритму

визначеного алгоритму управління кар'єрою проводиться відбір кандидатів для навчання y ВНЗ із військовослужбовиів.

Формування схеми (шаблону) кар'єри, планування та супроводження кар'єри особового складу передбачає використання офіцерського, сержантського, старшинського та рядового складу. Для прикладу на рис. 3 наведено алгоритм дій посадових осіб кадрових органів щодо управління кар'єрою офіцерського складу.

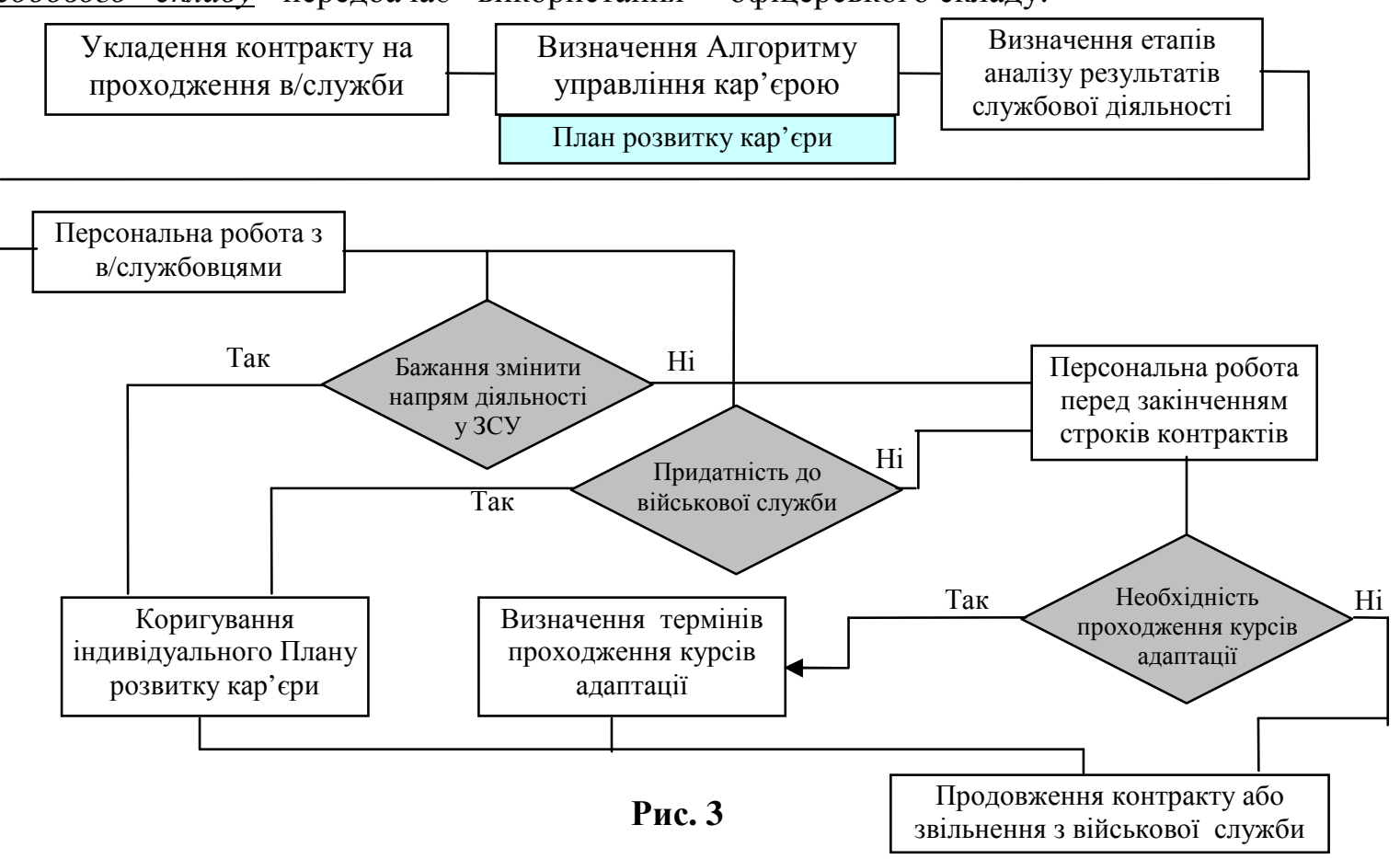

Вихідними даними для управління кар'єрою є: кваліфікаційні вимоги до осіб, що претендують на зайняття визначеної посади; оцінки та атестаційні характеристики; планування та заміщення. При цьому враховуються кваліфікаційні вимоги до кандидатів. Роботи по виконанню процесу “Управління кар'єрою офіцерів" здійснюються згідно із Законом України "Про військовий обов'язок і військову службу”.

Наведений аналіз дає змогу дійти висновку, що для побудови ЗС України використовується багаторівневий принцип комплектування (рис. 4). тники.

Рівень 1 - Кадрові офіцери і контрак-

Рівень 2 - Організований резерв - особи певного віку, які мають досвід військової служби.

Рівень 3 - Запас - формується 3 осіб, які за віком, здоров' $є$ м чи з інших причин вийшли 3 попередніх рівнів. Завдання - забезпечення поповненням військ у разі затяжного конфлікту або широкомасштабних військових дій. 


\section{КОМПЛЕТУВАННЯ ЗБРОЙНИХ СИЛ УКРАЇНИ}

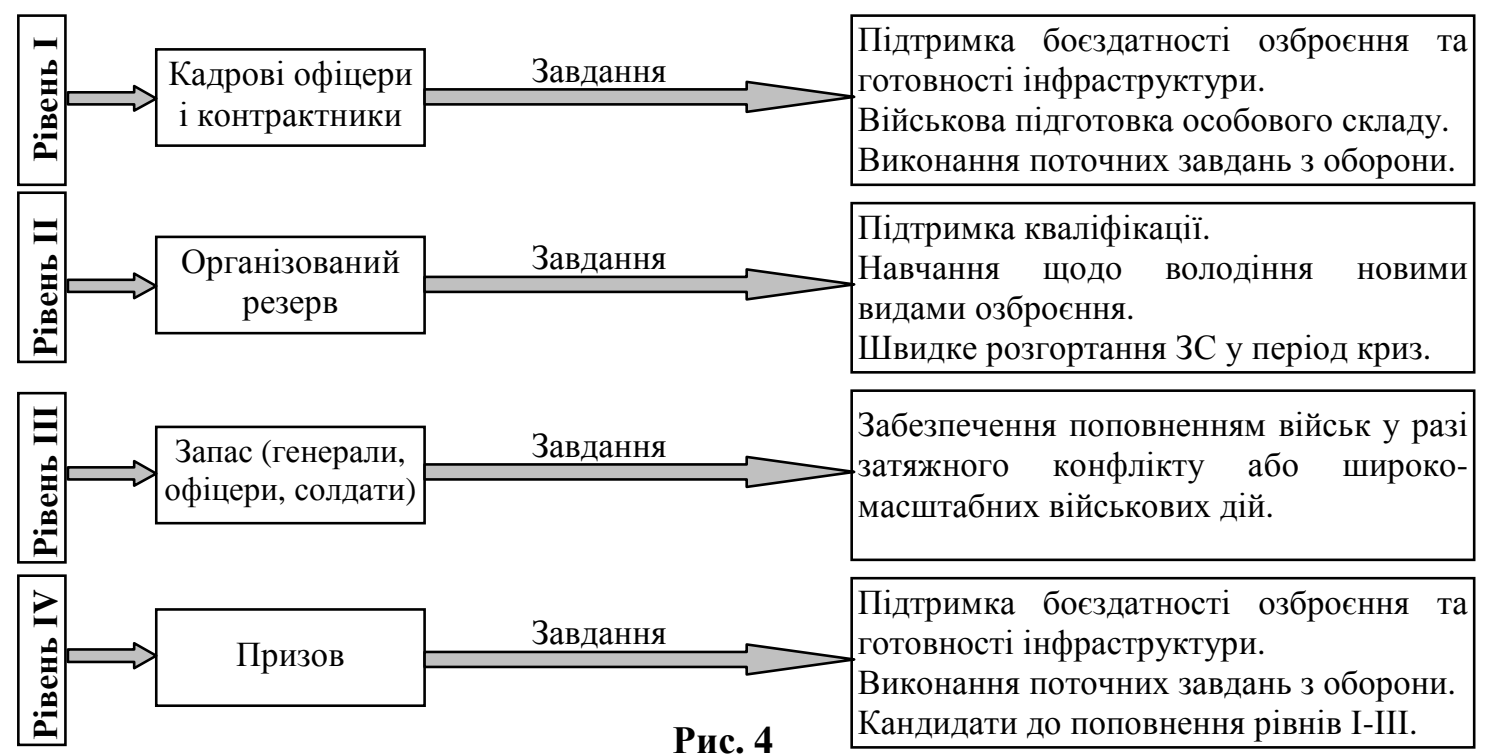

Piвень 4 - Призов -строкова військова служба; військова служба за призовом під час мобілізації, на особливий період; військова служба за призовом осіб офіцерського складу.

Така організація дає змогу невеликим складом регулярної армії та 3 мінімальними витратами підтримувати високу боєздатність
3C i, в найкоротші терміни, багаторазово збільшувати їх чисельність до необхідного рівня оборони.

Порядок відбору кандидатів до призначень на посади за рейтинговим принципом наведено на рис. 5.

\section{ПОРЯДОК ВІДБОРУ КАНДИДАТІВ ДО ПРИЗНАЧЕНЬ НА ПОСАДИ ЗА РЕЙТИНГОВИМ ПРИНЦИПОМ}

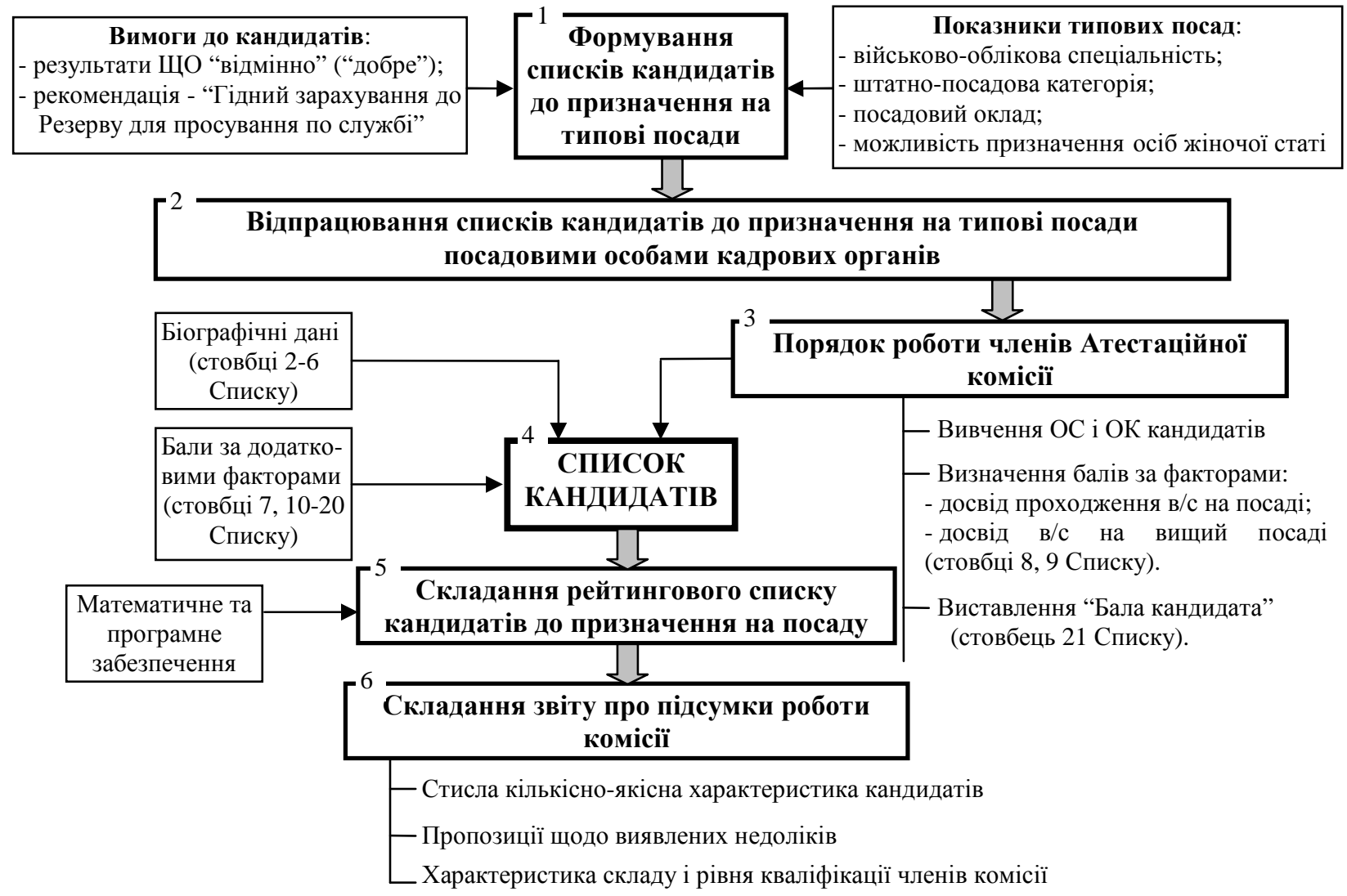

Рис. 5 
Аналіз порядку відбору кандидатів до призначень на посади за рейтинговим принципом дає змогу дійти висновку, що основна робота виконується секретарем відповідної Атестаційної комісії (блоки 1, 2, 46). Цей процес можна удосконалити шляхом створення автоматизованого робочого місия (АРМ) секретаря, яке забезпечить доступ до потрібних баз даних (БД), програмного забезпечення для складання рейтингового списку кандидатів до призначення на посаду та складання звіту про підсумки роботи комісії.

Аналіз та оцінка стану IAC, створених для автоматизації процесів обліку та управління персоналом ЗС України дає змогу дійти такого висновку:

- існуючі IAC $€$ вузькопрофільними, за виключенням IAC "Персонал” та підсистеми “Особовий склад” ЄСУ АГП ЗС України;

- проаналізовано функціональність розроблених систем стосовно: ведення організаційно-штатної структури; управління персоналом; формування звітності та обміну даними;

- найбільш повну функціональність мають IAC "Персонал" та підсистема “Особовий склад” ЄСУ АГП ЗС України;

- у підсистемі “Особовий склад” ЄСУ АГП ЗС України потребують налаштування такі підпроцеси: ведення обліку організаційних директив, подання на присвоєння наступного звання, підтримка та управління процесами 3 підготовки та рознесенню проектів наказів, ведення плану звільнення.

Висновки. Удосконалення системи управління ЗС України має базуватися на застосуванні новітніх методів управління, впровадженні сучасних інформаційних технологій, методів оперативного аналізу інформації, підтримки процесів прийняття рішень на основі інтегрованого інформаційного середовища.

Автоматизовані системи, які на сучасному етапі впроваджені у роботу кадрових органів МО України та 3С України, не мають функціональних можливостей щодо формування Резерву кандидатів для просування по службі та його використання під час підготовки і прийняття кадрових рішень але можуть надати загальну інформацію щодо військовослужбовця або військовозобов'язаного та результати щорічного оцінювання військовослужбовця.

Подальші дослідження доцільно зосередити на розробленні спеціального програмного забезпечення для складання рейтингового списку кандидатів до призначення на посаду та складання звіту про підсумки роботи Атестаційної комісії.

\section{СПИСОК ВИКОРИСТАНОЇ ЛІТЕРАТУРИ}

1. Состояние и перспективы политического урегулирования конфликта между Украиной и республиками Донбасса (аналитический доклад). Москва, 1916 год. Режим доступа http://cpkr.ru/sites/default/files/pdf/minsk2_inter.pdf

2. Аналитический портал Слово и дело. Шел четвертый год войны: когда закончится конфликт на Донбассе. Режим доступа https://ru.slovoidilo.ua/ 2017/11/01/mnenie/obshhestvo/shel-chetvertyj-godvojny-kogda-zakonchitsya-konflikt-donbasse

3. А.Е. Калинин Порядок прохождения военной службы в зарубежных государствах (США, Великобритания, Франция, ФРГ и др.). Режим доступа: http://zodorov.ru.

4. В. И. Андреев Сравнительный анализ подготовки офицеров в армиях зарубежных государств и Республики Беларусь. Наука и военная безопасность № 1/2007, стр. 58-63.

5. Матвеенко А. А. По зарубежным странам и армиям / Зарубежное военное обозрение. - 2000. № 1. - C. 26 - 39 .

6. Рибидайло А. А. Аналіз досвіду провідних країн світу щодо формування та використання кадрового резерву у збройних силах / Турейчук А. М., Прокопенко О. С./ Київ ЦВСД НУОУ, Збірник наукових праць, № 2(60), 2017 р.

7. Регламент по подбору персонала/ HR-лига (сообщество кадровиков и специалистов по управлению персоналом), 30.06.2009. Режим доступа: https://hrliga.com/index.php?module= profession \& op=view $\&$ id $=1098$. 
Рыбыдайло А. А., к.т.н., с.н.с.;

Турейчук А. Н., к.т.н.;

Прокопенко А. С.;

Дергилёва Е. В., к.т.н., с.н.с.

Центр военно-стратегических исследований Национального университета обороны Украины имени Ивана Черняховского, Киев

Формирование действенного резерва кандидатов для продвижения по службе и его использование во время подготовки и принятия кадровых решений

Резюме. Проведен анализ процесса управления личным составом относительно формирования и использования резерва кандидатов для продвижения по службе и управления карьерой военнослужащих. Обоснованы предложения по совершенствованию процесса формирования резерва по рейтинговому принципу путем применения ИТ-технологий.

Ключевые слова: кадровый резерв, комплектование вооруженных сил, автоматизированные системы управления персоналом.

\section{A. Rybydajlo, Ph.D, senior researcher;}

A. Tureychuk, Ph.D;

A. Prokopenko;

E. Dergilyova, Ph.D, senior researcher

Center for Military and Strategic Studies of the National Defence University of Ukraine named after Ivan Cherniakhovsky, Kyiv

Formation of an effective reserve of candidates for promotion and its use during the preparation and adoption of personnel decisions

Resume. The analysis of the personnel management process regarding the formation and use of candidates' reserve for promotion and career management of military personnel was conducted. The proposals for improving the process of forming a reserve by a rating principle based on the application of IT technologies are grounded.

Keywords: personnel reserve, recruitment of armed forces, automated personnel management systems. 